\title{
Combining intercropping with semiochemical releases: optimization of alternative control of Sitobion avenae 1 in wheat crops in China
}

\author{
Guang Wang ${ }^{1}$, Liang-Liang Cui ${ }^{1}$, Jie Dong ${ }^{1}$, Frédéric Francis ${ }^{2}$, Yong Liu ${ }^{1} *$ \& John Tooker ${ }^{3}$ \\ ${ }^{1}$ Department of Entomology, College of Plant Protection, Shandong Agricultural University, Taian, Shandong 271018, \\ China, ${ }^{2}$ Functional \& Evolutionary Entomology, Gembloux Agro-Bio-Tech, University of Liège, Gembloux, Belgium, \\ 2 and ${ }^{3}$ Department of Entomology, The Pennsylvania State University, University Park, PA, USA
}

Accepted: 25 May 2011

Key words: intercrop, methyl salicylate, oilseed rape, wheat aphid, natural enemy, diversification, sustainable control, Hemiptera, Aphididae, crop yield, parasitoid, predator

\section{Abstract}

\section{Introduction}

Efficiently controlling insect pest populations in agricultural crops is vital to optimizing yield and farm profitability. For cereal grains and many other crops produced in temperate climates, aphids are among the most challenging insect species to manage because their populations can increase quickly, their feeding can directly and indirectly damage the crop and influence yield, and they can vector yield-sapping pathogens (Van Emden \& Harrington, 2007). Among aphid species, the English grain aphid [Sitobion avenae (Fabricius) (Hemiptera: Aphididae)] can be particularly problematic (Vickerman \& Wratten, 1979; Hansen, 1995). This pest species attacks a range of small grains, feeding on phloem and spreading viruses (Van Em-

*Correspondence: Yong Liu, College of Plant Protection, Shandong Agricultural University, Taian, Shandong 271018, China.

E-mail: liuyong@sdau.edu.cn den \& Harrington, 2007). In wheat [Triticum aestivum L. (Poaceae)] production, S. avenae can frequently cause economic damage, necessitating routine insecticide use. To reduce reliance on this pesticide use and associated economic, environmental, and health costs, researchers are exploring alternative, more sustainable strategies for managing pest populations.

A substantial body of literature has illustrated that insect pests are less problematic in areas with increased plant species diversity (e.g., Andow, 1991; Landis et al., 2000). However, increasing local plant species diversity may be difficult for many growers. A simple within-field solution to increasing local plant species diversity is intercropping, which can reduce insect pest populations compared with monocultures (Andow, 1991; Landis et al., 2000; Smith \& McSorley, 2000). Oilseed rape, Brassica napus L. (Brassicaceae), is an economically important crop that has been widely used to examine the influence of crop diversification on abundance of arthropod pests and natural enemies

(C) 2011 The Authors Entomologia Experimentalis et Applicata 1-7, 2011

Entomologia Experimentalis et Applicata (C) 2011 The Netherlands Entomological Society

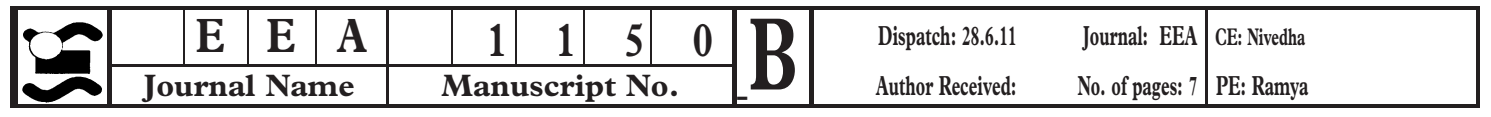


(Hooks \& Johnson, 2003). In China, oilseed rape intercropped with wheat has been demonstrated to significantly reduce the density of wheat aphids when compared to wheat monoculture (Wang et al., 2008, 2009).

In addition to intercropping, semiochemicals have also been shown to be useful for managing pest populations 3 (James, 2003, 2005; James al., 2004). Semiochemicals are natural chemical cues that mediate interactions between organisms such as plants and insects (Nordlund \& Lewis, 1976). When attacked by herbivorous arthropods, many, if not most, plant species release volatile compounds that can act as repellents for herbivores or as attractants for natural enemies of herbivores, such as predators and parasitoids (Takabayashi \& Dicke, 1996). Among semiochemicals, methyl salicylate (MeSA) is a volatile plant compound known to be very important for inducing resistance against pathogens and some herbivores (Shulaev et al., 1997). Methyl salicylate has also been demonstrated to be repellent to Rhopalosiphum padi (L.) and other cereal aphids (Pettersson et al., 1994; Glinwood \& Pettersson, 2000; Ninkovic et al., 2003), whereas it has increased abundance in crops of predaceous beetles (e.g., Coccinella septempunctata L., Stethorus punctum picipes Casey), lacewings (e.g., Chrysopa nigricornis Burmeister, Hemerobius spec.), and bugs [e.g., Deraeocoris brevis (Uhler) and Orius tristicolor (White)] (James, 2003, 2005;

4 James al., 2004; Zhu \& Papk, 2005).

Although both intercropping and semiochemicals can be effective in reducing aphid populations, to the best of our knowledge, thus far, these two tactics have been used independently. In this study, we combined the two tactics to determine whether the influences on aphid populations and crop yields of wheat intercropped with oilseed rape and MeSA release were additive or even synergistic.

\section{Materials and methods}

To test the combined influence of intercropping and semiochemical release on aphid populations, we conducted field experiments in two consecutive years at the experimental farm of Shandong Agricultural University, Shandong Province, China $\left(36^{\circ} 09^{\prime} \mathrm{N}, 117^{\circ} 09^{\prime} \mathrm{E}\right)$. For these experiments, we used wheat variety 'Lumai 2 ' and oilseed rape variety 'Yuyou 5'. Both varieties are currently used commercially in China, for instance in provinces Shandong and Henan. For the semiochemical portion of the experiments, MeSA ( $\geq 99.7 \%$ ) was obtained from the Chinese Academy of Military Medical Sciences.

\section{Field experiments}

The field experiments comprised four treatments: (1) wheat monocultures, (2) wheat intercropped with oilseed rape, (3) MeSA release in wheat crop, and (4) wheat intercropped with oilseed rape and MeSA release. The four treatments were arranged in a completely randomized design with $10 \times 10$-m plots, and each treatment was replicated three times. Plots were bordered on all sides by $10-$ $\mathrm{m}$-wide paths to decrease the possibility of natural enemies dispersing among treatments. Experimental fields were established in fall when wheat and oilseed rape were planted. Wheat was planted in $20-\mathrm{cm}$-apart rows at a rate of $120 \mathrm{~kg} \mathrm{ha}^{-1}$ on 11 and 15 October in 2007 and 2008 , respectively. Oilseed rape was grown at the same time with wheat and kept in a greenhouse until seedlings were transplanted into the field plots on 10 November of each year. Seedlings had six true leaves at transplanting. Oilseed rape plants were spaced $40 \mathrm{~cm}$ apart within plots. Intercropped plots had eight rows of wheat, two rows of oilseed rape, and then the pattern repeated (Wang et al., 2009). All treatments were fertilized with 150:50:25 (NPK) $\mathrm{kg} \mathrm{ha}^{-1}$, and no insecticides or herbicides were used in the whole experimental area. Plots were irrigated twice in each year, once during seedling establishment and once during seed fill.

To release MeSA, we used a slow-release apparatus based on a small cylindrical plastic box (inner diameter $6.5 \mathrm{~cm}, 4 \mathrm{~cm}$ tall) containing a sponge. The chemical was injected into the sponge inside the box, which had four 2$\mathrm{cm}$ holes drilled through the top. The plastic boxes were attached to crabsticks and spaced $1 \mathrm{~m}$ above the ground, set at the center of each plot, one box for each plot. Boxes emitted doses of $120 \mathrm{mg} \mathrm{MeSA} \mathrm{m}^{-2}$ per week, which was based on a previous study (Pettersson et al., 1994). The first application of MeSA was made at the jointing stage on 16 and 17 April, in 2008 and 2009, respectively, and subsequently applied every 7 days, for four times in 2008 and five times in 2009.

\section{Sampling of wheat aphids and natural enemies}

To evaluate the influence of the four treatments on insect populations, we sampled plots for $S$. avenae and its predators and parasitoids. To sample $S$. avenae, we used a 'Zshaped' sampling pattern in which 10 sampling sites were selected within each plot. At each sampling site, we randomly selected 10 wheat tillers and counted the $S$. avenae on all the tillers ( 10 sites, 10 tillers per site: 100 tillers per plot). For predatory lady beetles (i.e., C. septempunctata, Harmonia axyridis Pallas, and Propylaea japonica Thunberg), we counted all stages of beetles found on wheat plants within five quadrates randomly positioned within each plot, each quadrate was $0.2 \mathrm{~m}^{2}$. For aphid parasitoids (i.e., Aphidius avenae Haliday and Aphidius gifuensis Ashmead), we counted the aphid mummies on the same 100 wheat tillers mentioned above for S. avenae. Parasitism 
rates (derived from mummy counts) were calculated at the end of each sampling period. Insect species were sampled at 3-day intervals from 16 April to 22 May in 2008 and from 17 April to 23 May in 2009 (from wheat jointing stage to mature stage).

\section{Statistical analysis}

Population densities of insect species were compared among treatments using analysis of variance (ANOVA), followed by comparison of means using Duncan's multiple range test. In both years, yield (tonnes $\mathrm{ha}^{-1}$ ) and thousand grain weight (TGW; g) were calculated for each treatment. These data were analyzed by one-way ANOVA followed by Duncan's multiple range test. Effects of years and treatments and the possible interaction between wheat-oilseed rape intercropping and MeSA release were analyzed using general linear model (GLM) procedure. Where necessary, the data used in ANOVA and GLM were transformed using $\sqrt{ } \mathrm{x}$ to meet assumptions of normality (SPSS for Win-

5 dows, version 16.0).

\section{Results}

\section{Maximum Sitobion avenae densities}

In both 2008 and 2009, significant differences were detected in maximum S. avenae densities per 100 tillers between the control and the three other treatments (2008: $\mathrm{F}_{3,8}=107.64, \mathrm{P}<0.01 ; 2009: \mathrm{F}_{3,8}=44.08, \mathrm{P}<0.01$; Table 1). In both years, aphid maximum densities were lowest in the combined intercropping-MeSA plots compared to the other three treatments. No significant difference was detected between intercropping-alone and MeSA-alone plots.

\section{Aphid densities, predatory lady beetles, and parasitoids of Sitobion}

\section{avenae}

In both 2008 and 2009, significant differences were detected in the mean numbers of aphids per 100 tillers

Table 1 Effects of treatments on mean $( \pm$ SE) maximum Sitobion avenae densities during 2008 and 2009

\begin{tabular}{lrl}
\hline & \multicolumn{2}{l}{ Year } \\
\cline { 2 - 3 } Treatment & 2008 & 2009 \\
\hline Control & $2483 \pm 77 \mathrm{a}$ & $2218 \pm 76 \mathrm{a}$ \\
Wheat-oilseed rape intercropping & $1120 \pm 77 \mathrm{~b}$ & $1145 \pm 83 \mathrm{~b}$ \\
MeSA release in wheat crop & $1320 \pm 71 \mathrm{~b}$ & $1361 \pm 67 \mathrm{~b}$ \\
Intercropping with MeSA release & $761 \pm 60 \mathrm{c}$ & $935 \pm 106 \mathrm{c}$ \\
\hline
\end{tabular}

MeSA, methyl salicylate.

Means in the same column followed by different letters are significantly different (Duncan's multiple range test: $\mathrm{P}<0.05$ ). between the control and the other three treatments (2008: $\mathrm{F}_{3,8}=97.58, \mathrm{P}<0.01 ; 2009: \mathrm{F}_{3,8}=90.11, \mathrm{P}<0.01$; Figure $1 \mathrm{~A})$. The average densities of wheat aphids were highest in control plots and lowest in combined intercropping-MeSA plots. No significant difference in aphid densities was detected between MeSA and intercropped plots.

Consistent with our results for aphid densities, predatory lady beetles were most abundant in combined intercrop-MeSA plots, and these populations were significantly more abundant than intercropped-alone or MeSA-alone plots, which contained in turn significantly more predatory lady beetles than monoculture controls (2008: $\mathrm{F}_{3,8}=15.43, \mathrm{P}<0.01 ; 2009: \mathrm{F}_{3,8}=23.59, \mathrm{P}<0.01 ;$ Figure $1 \mathrm{~B})$. Mean parasitism rates of $S$. avenae showed a pattern similar to that of lady beetles $\left(2008: \mathrm{F}_{3,8}=11.22\right.$, $\mathrm{P}<0.01 ; 2009: \mathrm{F}_{3,8}=18.32, \mathrm{P}<0.01$; Figure 1C).

\section{Yield and quality}

In both years, yield and TGW differed significantly between treatments (yield, 2008: $\mathrm{F}_{3,8}=15.32, \mathrm{P}<0.01$; 2009: $\mathrm{F}_{3,8}=11.39, \mathrm{P}<0.01 ;$ TGW, 2008: $\mathrm{F}_{3,8}=15.94$, $\mathrm{P}<0.01 ; 2009: \mathrm{F}_{3,8}=9.51, \mathrm{P}<0.01$; Table 2). Yield and TGW in combined intercrop-MeSA plots were significantly higher than in the other three plots. However, in 2008, no significant difference was detected among the other three treatments in yield, whereas in 2009, no significant difference in TGW was detected between intercropped and monoculture plots.

\section{Two-factor effects}

In addition to within-year analyses, we also compared results across years with two-factor ANOVA (Table 3). Between the 2 years, yield and aphid density were not significantly different, but we did detect significant differences in the number of lady beetles, parasitism rate, and TGW. Other than for parasitism rates, no significant difference was detected in interactions between year and treatments (Table 3). Between the 2 years, we also detected significant interactions between intercropping and MeSA release treatment for aphids, but no significant interaction was detected for lady beetles, parasitism rates, yields, and TGWs (Table 4).

\section{Discussion}

Our results support the combined power of intercropping and semiochemical release. Control of aphids attained when the two approaches were combined was significantly improved compared to intercropping and MeSA release individually. In fact, the effect on aphid control was so strong than the two tactics seemed to act in synergy. The mechanism of this improved control might have been due 
A

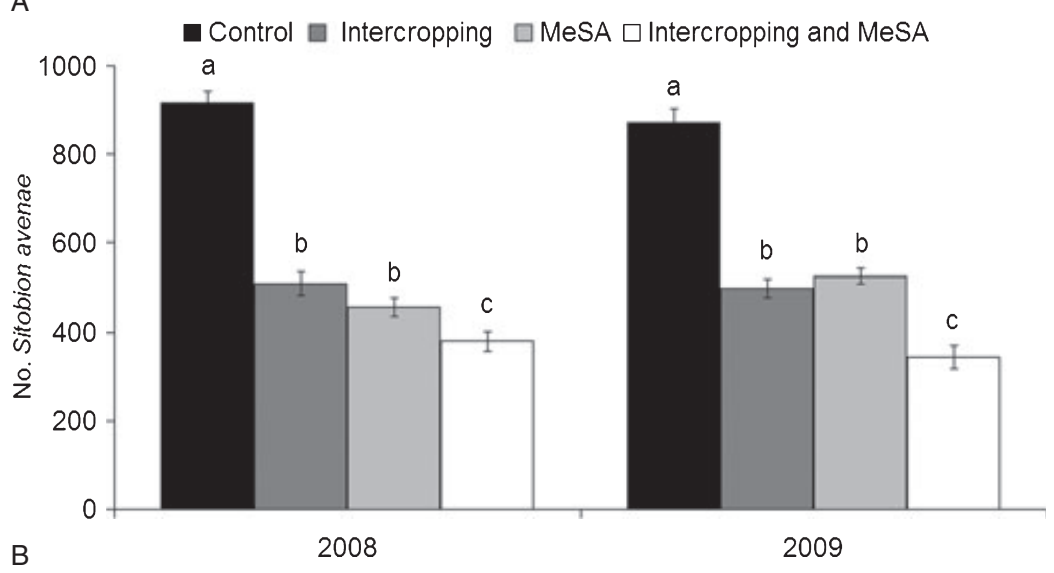

B

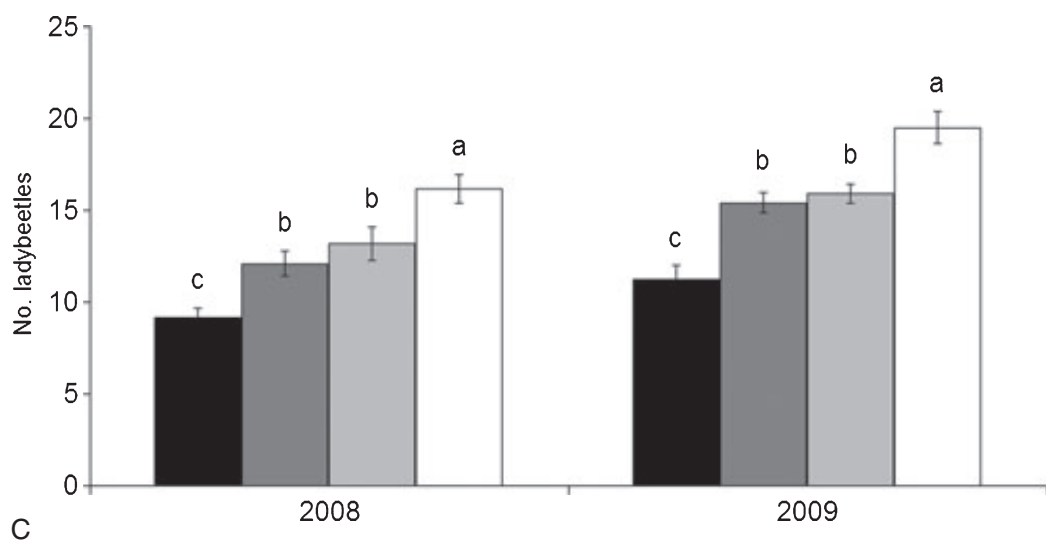

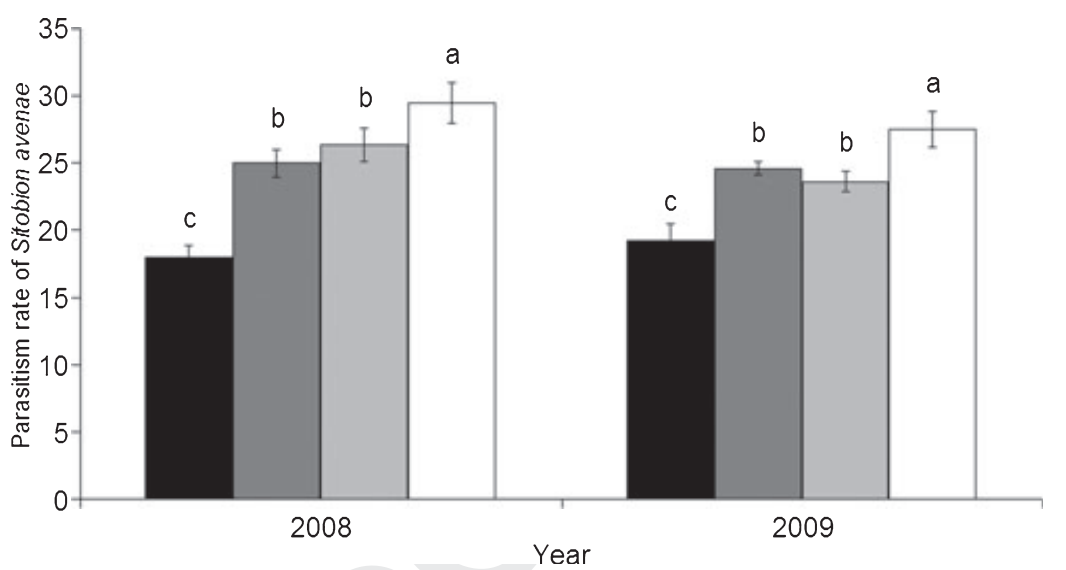

Figure 1 Field experiment testing the influence of four treatments (wheat monoculture, wheat intercropped with oilseed rape, methyl salicylate (MeSA) release in wheat crop, and the combination of MeSA and wheat-oilseed intercrop) on insect populations (mean number per 100 tillers \pm SE). (A) Sitobion avenae, (B) lady beetles, and (C) S. avenae parasitized. Bars capped with different letters within a year are significantly different (Duncan's multiple range test: $\mathrm{P}<0.05)$. to two factors. First, MeSA may have been directly repellent to $S$. avenae, reducing initial aphid colonization early in the season (Pettersson et al., 1994). Alternatively, MeSA may have increased the mobility of aphids, enhancing their exposure to predators (Griffiths et al., 1985; Sunderland et al., 1986). Increased mobility may also have reduced time spent in optimal feeding sites, preventing populations from growing as quickly as they could (Wiktelius, 1989). Second, combined MeSA and intercropping plots may have developed larger populations of natural enemies that killed more aphids. This notion was supported by the greater numbers of lady beetles and parasitized aphids in combined plots (Figure 1B and C). These natural enemies could have been attracted to plots by MeSA (Zhu et al., 1999; Kean et al., 2003; James \& Price, 2004; Prinsloo et al., 2007) and then maintained within the combined plots by alternative prey provided by intercropped plants. As for some other natural enemy species 
Table 2 Mean ( \pm SE) yield and thousand grain weight (TGW) of wheat in treatment plots

\begin{tabular}{|c|c|c|c|c|}
\hline \multirow[b]{2}{*}{ Treatment } & \multicolumn{2}{|c|}{ Yield (tonnes ha ${ }^{-1}$ ) } & \multicolumn{2}{|l|}{ TGW (g) } \\
\hline & 2008 & 2009 & 2008 & 2009 \\
\hline Control & $5.30 \pm 0.11 \mathrm{c}$ & $5.39 \pm 0.09 b$ & $31.52 \pm 1.10 \mathrm{c}$ & $30.09 \pm 1.55 c$ \\
\hline Wheat-oilseed rape intercropping & $5.88 \pm 0.19 b$ & $5.63 \pm 0.10 b$ & $36.02 \pm 1.19 b$ & $33.78 \pm 0.83 \mathrm{bc}$ \\
\hline MeSA releases in wheat crop & $6.06 \pm 0.12 b$ & $5.72 \pm 0.18 b$ & $37.35 \pm 0.38 b$ & $34.05 \pm 0.38 b$ \\
\hline Intercropping with MeSA releases & $6.65 \pm 0.14 \mathrm{a}$ & $6.42 \pm 0.13 \mathrm{a}$ & $41.38 \pm 1.18 \mathrm{a}$ & $38.7 \pm 1.41 \mathrm{a}$ \\
\hline
\end{tabular}

MeSA, methyl salicylate.

Means in the same column followed by different letters are significantly different (Duncan's multiple range test: $\mathrm{P}<0.05$ ).

Table 3 F-statistics for effect of year and treatment on abundance of Sitobion avenae, lady beetles, parasitism rate, yield, and thousand grain weight (TGW)

\begin{tabular}{|c|c|c|c|c|c|c|}
\hline \multirow[b]{2}{*}{ Source of variation } & \multirow[b]{2}{*}{ d.f. } & \multicolumn{5}{|l|}{ F-value } \\
\hline & & Aphids & Lady beetles & Parasitism rate & Yield & TGW \\
\hline Treatment & 3 & $190.84^{\star \star}$ & $38.19^{* *}$ & $71.04^{\star *}$ & $26.04^{\star *}$ & $24.44^{\star *}$ \\
\hline Year & 1 & $0.44 \mathrm{~ns}$ & $31.93^{\star *}$ & $196.32^{\star *}$ & $3.42 \mathrm{~ns}$ & $9.90^{* *}$ \\
\hline Treatment ${ }^{*}$ year & 3 & $2.82 \mathrm{~ns}$ & $0.33 \mathrm{~ns}$ & $6.62^{\star * *}$ & $0.97 \mathrm{~ns}$ & $0.27 \mathrm{~ns}$ \\
\hline
\end{tabular}

${ }^{*} \mathrm{P}<0.01$, ns: $\mathrm{P}>0.05$.

Table 4 F-statistics for effect of wheat-oilseed rape intercropping and methyl salicylate (MeSA) releases on abundance of Sitobion avenae, lady beetles, parasitism rate, yield, and thousand grain weight (TGW)

\begin{tabular}{|c|c|c|c|c|c|c|}
\hline \multirow[b]{2}{*}{ Year } & \multirow[b]{2}{*}{ Source of variation } & \multicolumn{5}{|l|}{ F-values } \\
\hline & & Aphids & Lady beetles & Parasitism rate & Yield & TGW \\
\hline \multirow[t]{3}{*}{2008} & Intercropping & $99.68^{*}$ & $16.03^{*}$ & $19.48^{*}$ & $16.99^{*}$ & $13.31^{*}$ \\
\hline & MeSA & $147.01^{*}$ & $30.25^{\star}$ & $12.85^{\star}$ & $29.68^{\star}$ & $15.04^{*}$ \\
\hline & Intercropping ${ }^{\star} \mathrm{MeSA}$ & $46.06^{\star}$ & $1.29 \mathrm{~ns}$ & $1.33 \mathrm{~ns}$ & $0.06 \mathrm{~ns}$ & $0.18 \mathrm{~ns}$ \\
\hline \multirow[t]{3}{*}{2009} & Intercropping & $139.81^{*}$ & $31.14^{\star}$ & $19.88^{\star}$ & $12.55^{\star}$ & $17.56^{*}$ \\
\hline & MeSA & $113.66^{*}$ & $39.47^{\star}$ & $33.47^{\star}$ & $18.01^{\star}$ & $30.21^{*}$ \\
\hline & Intercropping ${ }^{\star} \mathrm{MeSA}$ & $16.87^{\star}$ & $1.65 \mathrm{~ns}$ & $1.62 \mathrm{~ns}$ & $2.69 \mathrm{~ns}$ & $0.05 \mathrm{~ns}$ \\
\hline
\end{tabular}

${ }^{\star} \mathrm{P}<0.05, \mathrm{~ns}: \mathrm{P}>0.05$.

(e.g., spiders, lacewings, and syrphids), their numbers were too small to have any significant effect on the aphids. On oilseed rape plants, we found at least two other aphid species [Myzus persicae Sulzer and Lipaphis erysimi (Kaltenbach)], which could have served as alternative hosts for a parasitoid (i.e., A. gifuensis) and predators (i.e., P. japonica, H. axyridis, and C. septempunctata) during the early stage of wheat growth, because these two aphid species reach their peaking period about 10 days earlier than that of $S$. avenae in intercropping plots.

6 Yield and TWG were significantly higher in combined intercropped and MeSA plots than in plots of the other three treatments in 2008 and 2009. In 2009, we found no significant difference in yields among the other three treatments and no difference in TWG between the control and intercropping plot. Differences in yield and TWG may have been due to various degrees of aphid exposure that is caused by differential populations of natural enemies in different treatment plots.

Increased plant species diversity in agroecosystems can improve abundance of natural enemies by providing them nectar, pollen, or alternative prey, which can prolong their lives and increase the number of herbivores they can kill in a lifetime (Pemberton \& Lee, 1996; Ruhren \& Handel, 1999; Cuautle \& Rico-Gray, 2003). The flowering period of oilseed rape in Shandong province is from 15 to 30 
April, more than 8 days before the $S$. avenae population peak. Therefore, oilseed rape likely provided alternative resources, such as floral nectar and/or pollen, that benefited natural enemies and facilitated improved pest control. As mentioned earlier, we found other aphid species that could have helped support natural enemies in intercrop-MeSA plots.

Although wheat-oilseed rape intercropping enhanced the abundance of predators and parasitoids, they may have failed to suppress the initial aphid colonization of wheat, because at the time of transplant of the young small oilseed rape plants and the wheat seedlings, there was abundant bare soil in those plots. Aphids locate potential host plants by contrasting the plant with the soil background (Kennedy et al., 1959, 1961), so the appearance of bare soil may have encouraged aphids to preferentially colonize wheat in wheat-oilseed rape intercropping fields. Alternatively, as a repellent to $S$. avenae and an attractant to its natural enemies, MeSA release in intercropped plots may have offset initial aphid colonization, enhancing the killing action of predators and parasitoids.

Our results strongly support the efficacy of combining intercropping and semiochemical release to attain improved pest control in small grain production. Whereas these two tactics have been shown to improve pest control independently, their combined power is even greater. Based on the simplicity of each tactic, there would appear to be only a few minor barriers to adoption by growers. Given widespread adoption, integrating these two tactics would appear to hold great promise for improving sustainable pest management while reducing reliance on insecticides.

\section{Acknowledgements}

We thank the international cooperation Shandong project, with financial support of the Cooperation Universiataire au Developpement (CUD) from Belgium, and the National Science and Technology project (2010 DFA 32810) for funding. Thanks also to the Cotton and Oil Crop Institute of Henan Academy of Agricultural Sciences at Zhengzhou, Henan, for supplying oilseed rape variety 'Yuyou 5'. We thank the two anonymous reviewers for their constructive comments.

\section{References}

Andow DA (1991) Vegetational diversity and arthropod population response. Annual Review of Entomology 36: 561-586.

Cuautle M \& Rico-Gray V (2003) The effect of wasps and ants on the reproductive success of the extrafloral nectaried plant Turnera ulmifolia (Turneraceae). Functional Ecology 17: 417-423.
Glinwood RT \& Pettersson J (2000) Change in response of Rhopalosiphum padi spring migrants to the repellent winter host component methyl salicylate. Entomologia Experimentalis et Applicata 94: 325-330.

Griffiths E, Wratten SD \& Vickerman GP (1985) Foraging by the carabid Agonum dorsale in the field. Ecological Entomology 10: 181-189.

Hansen LM (1995) Aphids - the national pest in Denmark. 12th Danish Plant Protection conference, pest and diseases. SPRapport-Statens Planteavlsforsog 4: 115-128.

Hooks CRR \& Johnson MW (2003) Impact of agricultural diversification on the insect community of cruciferous crops. Crop Protection 22: 223-238.

James DG (2003) Field evaluation of herbivore-induced plant volatiles as attractants for beneficial insects: methyl salicylate and the green lacewing, Chrysopa nigricornis. Journal of Chemical Ecology 7: 1601-1609.

James DG (2005) Further field evaluation of synthetic herbivoreinduced plant volatiles as attractants for beneficial insects. Journal of Chemical Ecology 31: 481-495.

James DG \& Price TS (2004) Field-testing of methyl salicylate for recruitment and retention of beneficial insects in grapes and hops. Journal of Chemical Ecology 30: 1613-1628.

Kean J, Wratten S, Tylianakis J \& Barlow J (2003) The population consequences of natural enemy enhancement and implications for conservation biological control. Ecology Letters 6: 604612.

Kennedy JS, Booth CO \& Kershaw WJS (1959) Host finding by aphids in the field. II. Aphis fabae Scop. (Gynoparae) and Brevicoryne brassicae L. with a reappraisal of the role of host finding behaviour in virus spread. Annals of Applied Biology 47: 424444.

Kennedy JS, Booth CO \& Kershaw WJS (1961) Host finding by aphids in the field. III. Visual attraction. Annals of Applied Biology 49: 1-21.

Landis DA, Wratten SD \& Gurr GM (2000) Habitat management to conserve natural enemies of arthropod pests in agriculture. Annual Review of Entomology 45: 175-201.

Ninkovic V, Ahmed E, Glinwood R \& Pettersson J (2003) Effects of two types of semiochemical on population development of the bird cherry oat aphid Rhopalosiphum padi in a barley crop. Agricultural and Forest Entomology 5: 27-33.

Nordlund DA \& Lewis WJ (1976) Terminology of chemical releasing stimuli in intraspecific and interspecific interactions. Journal of Chemical Ecology 2: 211-220.

Pemberton RW \& Lee JH (1996) The influence of extrafloral nectaries on parasitism of an insect herbivore. American Journal of Botany 83: 1187-1194.

Pettersson J, Pickett JA, Pye BJ, Quiroz A, Smart LE et al. (1994) Winter host component reduces colonization by bird-cherryoat aphid, Rhopalosiphum padi (L.) (Homoptera, Aphididae), and other aphids in cereal fields. Journal of Chemical Ecology 20: 2565-2575.

Prinsloo G, Ninkovic V, van der Linde TC, van der Westhuizen AJ, Pettersson J \& Glinwood R (2007) Test of semiochemicals and a resistant wheat variety for Russian wheat aphid 
management in South Africa. Journal of Applied Entomology 131: 637-644.

Ruhren S \& Handel SN (1999) Jumping spiders (Salticidae) enhance the seed production of a plant with extrafloral nectaries. Oecologia 119: 227-230.

Shulaev V, Silverman P \& Raskin I (1997) Airborne signaling by methyl salicylate in plant pathogen resistance. Nature 385: 718-721.

Smith HA \& McSorley R (2000) Intercropping and pest management: a review of major concepts. American Entomologist 46: 154-161.

Sunderland KD, Fraser AM \& Dixon AFG (1986) Field and laboratory studies on money spiders (Lynyphiidae) as predators of aphids. Journal of Applied Ecology 23: 433-447.

Takabayashi J \& Dicke M (1996) Plant-carnivore mutualism through herbivore-induced carnivore attractants. Trends in Plant Science 1: 109-113.

Van Emden HF \& Harrington R (2007) Aphids as Crop Pests. CABI Publishing, London, UK.

Vickerman GP \& Wratten SD (1979) The biology and pest status of cereal aphids (Hemiptera: Aphididae) in Europe: a review. Bulletin of Entomological Research 69: 1-32.
Wang WL, Liu Y, Ji XL, Wang G \& Zhou HB (2008) Impact of intercropping wheat cultivars with oilseed rape and garlic on population dynamics of wheat aphid (Sitobion avenae) and its natural enemies. Chinese Journal of Applied Ecology 19: 13311336.

Wang WL, Liu Y, Chen JL, Ji XL, Zhou HB \& Wang G (2009) Impact of intercropping aphid-resistant wheat cultivars with oilseed rape on wheat aphid (Sitobion avenae) and its natural enemies. Acta Ecologica Sinica 29: 186-191.

Wiktelius S (1989) Migration of apterous Rhopalosiphum padi. IOBC/WPRS Bulletin 12: 1-6.

Zhu JW \& Papk C (2005) Methyl salicylate, a soybean aphidinduced plant volatile attractive to the predator Coccinella septempunctata. Journal of Chemical Ecology 31: 1733-1739.

Zhu J, Cosse AA, Obrycki JJ, Boo KS \& Baker TC (1999) Olfactory reactions of the twelve-spotted lady beetle, Coleomegilla maculata and the green lacewing, Chrysoperla carnea to semiochemicals released from their prey and host plants: electroantennogram and behavioral responses. Journal of Chemical Ecology 25: 1163-1177. 


\section{Author Query Form}

Journal: $\quad$ EEA

Article: $\quad 1150$

Dear Author,

During the copy-editing of your paper, the following queries arose. Please respond to these by marking up your proofs with the necessary changes/additions. Please write your answers on the query sheet if there is insufficient space on the page proofs. Please write clearly and follow the conventions shown on the attached corrections sheet. If returning the proof by fax do not write too close to the paper's edge. Please remember that illegible mark-ups may delay publication.

Many thanks for your assistance.

\begin{tabular}{|c|c|c|}
\hline Query reference & Query & Remarks \\
\hline Q1 & AUTHOR: Please check and approve the edit made in the article title. & Yes \\
\hline Q2 & $\begin{array}{l}\text { AUTHOR: Journal style requires that the full postal address should be given. } \\
\text { Please check and provide missing details. }\end{array}$ & W echecked \\
\hline Q3 & $\begin{array}{l}\text { AUTHOR: James et al., } 2004 \text { has not been included in the Reference List, } \\
\text { please supply full publication details. }\end{array}$ & $\begin{array}{l}\text { Replaced of } \\
\text { James\& Price, } 2004\end{array}$ \\
\hline Q4 & $\begin{array}{l}\text { AUTHOR: Zhu et al., } 2005 \text { has been changed to Zhu and Papk, } 2005 \text { so that } \\
\text { this citation matches the Reference List. Please confirm that this is correct. }\end{array}$ & Yes \\
\hline Q5 & $\begin{array}{l}\text { AUTHOR: Please give manufacturer information for 'SPSS': company name, } \\
\text { town, state (if USA), and country. }\end{array}$ & SPSScompany, Illinois, USA \\
\hline Q6 & AUTHOR: Please define ‘TWG'. & Replaced of TGW \\
\hline Q7 & $\begin{array}{l}\text { AUTHOR: Please check the journal title 'Chinese Journal of Applied Ecol- } \\
\text { ogy'. }\end{array}$ & Yes, it'sright \\
\hline
\end{tabular}




\section{USING E-ANNOTATION TOOLS FOR ELECTRONIC PROOF CORRECTION}

\section{Required Software}

Adobe Acrobat Professional or Acrobat Reader (version 7.0 or above) is required to e-annotate PDFs. Acrobat 8 Reader is a free download: http://www.adobe.com/products/acrobat/readstep2.html

Once you have Acrobat Reader 8 on your PC and open the proof, you will see the Commenting Toolbar (if it does not appear automatically go to Tools>Commenting>Commenting Toolbar). The Commenting Toolbar looks like this:

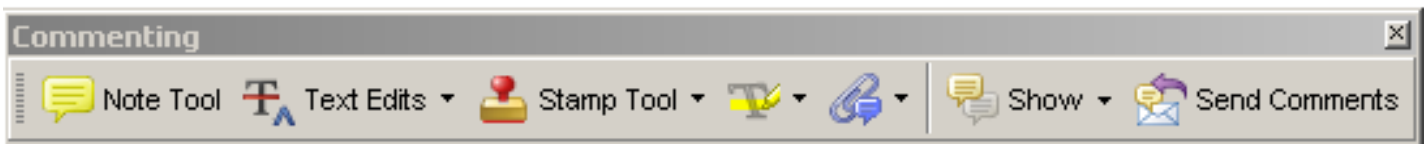

If you experience problems annotating files in Adobe Acrobat Reader 9 then you may need to change a preference setting in order to edit.

In the "Documents" category under "Edit - Preferences", please select the category 'Documents' and change the setting "PDF/A mode:" to "Never".

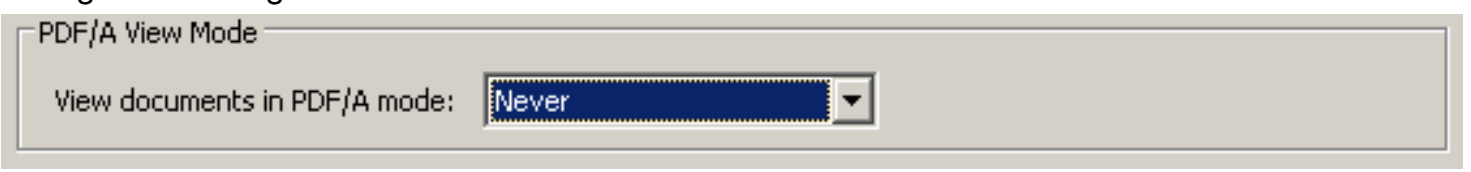

\section{Note Tool - For making notes at specific points in the text}

Marks a point on the paper where a note or question needs to be addressed.

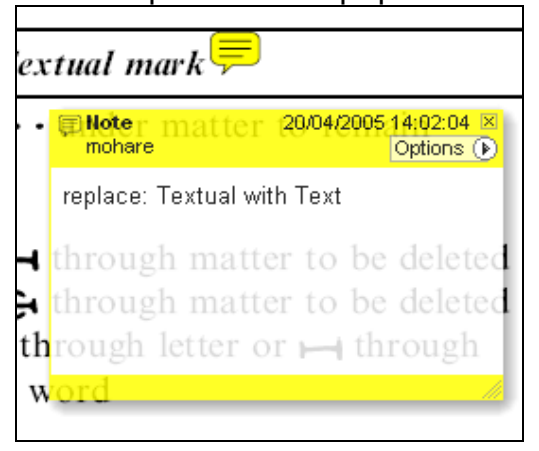

How to use it:

1. Right click into area of either inserted text or relevance to note

2. Select Add Note and a yellow speech bubble symbol and text box will appear

3. Type comment into the text box

4. Click the $X$ in the top right hand corner of the note box to close.

Replacement text tool - For deleting one word/section of text and replacing it

Strikes red line through text and opens up a replacement text box.

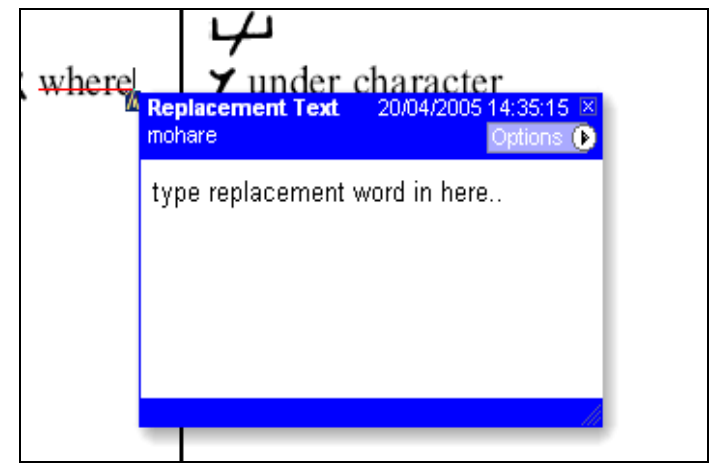

\section{How to use it:}

1. Select cursor from toolbar

2. Highlight word or sentence

3. Right click

4. Select Replace Text (Comment) option

5. Type replacement text in blue box

6. Click outside of the blue box to close

Cross out text tool - For deleting text when there is nothing to replace selection Strikes through text in a red line.

\begin{tabular}{|l|}
\hline substitute part of one or \\
more word(s) \\
Change to italies \\
Change to capitals \\
Change to small capitals \\
\hline
\end{tabular}
How to use it:
1. Select cursor from toolbar
2. Highlight word or sentence
3. Right click
4. Select Cross Out Text 


\section{(W)WILEY-BLACKWELL}

Approved tool - For approving a proof and that no corrections at all are required.

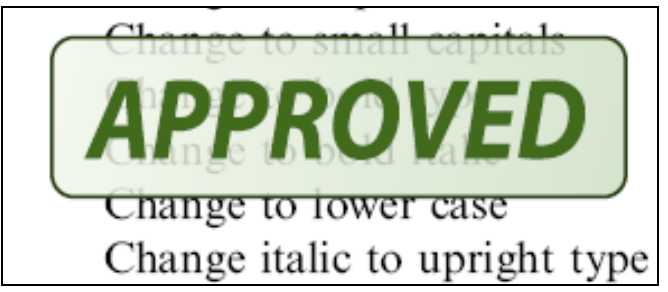

How to use it:

1. Click on the Stamp Tool in the toolbar

2. Select the Approved rubber stamp from the 'standard business' selection

3. Click on the text where you want to rubber stamp to appear (usually first page)

Highlight tool — For highlighting selection that should be changed to bold or italic. Highlights text in yellow and opens up a text box.

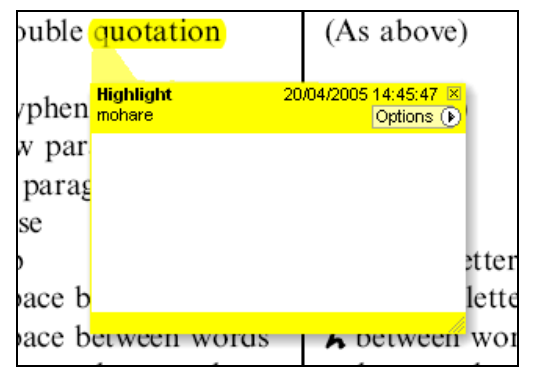

How to use it:

1. Select Highlighter Tool from the commenting toolbar

2. Highlight the desired text

3. Add a note detailing the required change

Attach File Tool - For inserting large amounts of text or replacement figures as a files. Inserts symbol and speech bubble where a file has been inserted.

\section{matter to be changed matter to matter to be changed matter to be changed} How to use it:

1. Click on paperclip icon in the commenting toolbar

2. Click where you want to insert the attachment

3. Select the saved file from your PC/network

4. Select appearance of icon (paperclip, graph, attachment or tag) and close

\section{Pencil tool - For circling parts of figures or making freeform marks}

Creates freeform shapes with a pencil tool. Particularly with graphics within the proof it may be useful to use the Drawing Markups toolbar. These tools allow you to draw circles, lines and comment on these marks.

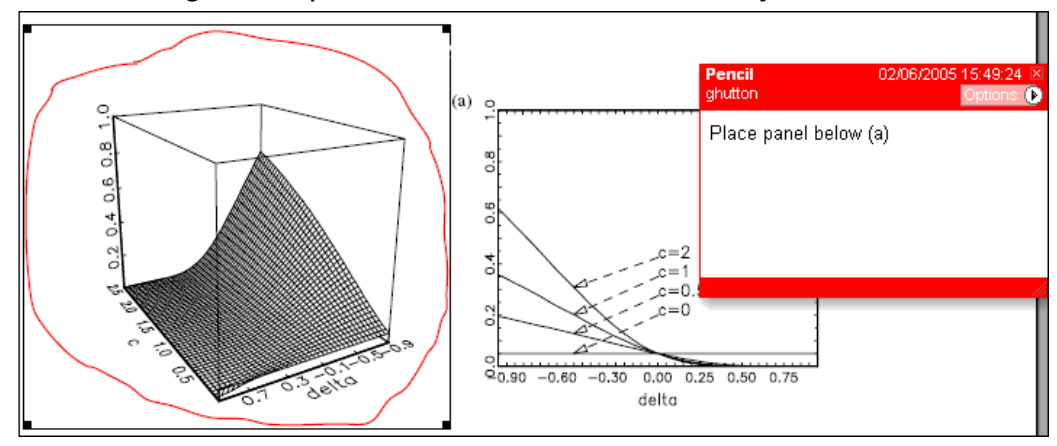

How to use it:

1. Select Tools $>$ Drawing Markups $>$ Pencil Tool

2. Draw with the cursor

3. Multiple pieces of pencil annotation can be grouped together

4. Once finished, move the cursor over the shape until an arrowhead appears and right click

5. Select Open Pop-Up Note and type in a details of required change

6. Click the $\mathrm{X}$ in the top right hand corner of the note box to close. 


\section{WILEY-BLACKWELL}

Help

For further information on how to annotate proofs click on the Help button to activate a list of instructions:

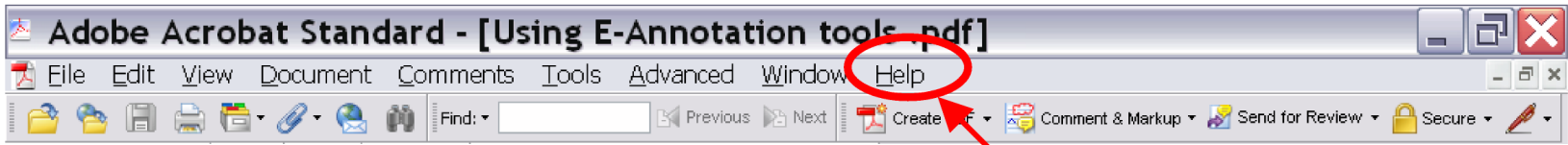

